\title{
Evaluation of Tourism Status in Sustainable Rural Development by Reynard Model (Case Study: Pa Ghaleh Village, Mamasani County, Iran)
}

\author{
Ali Shamsoddini \\ Department of Geography, Marvdasht Branch, Islamic Azad University, Marvdasht, Iran \\ Email: Ali.shamsoddini@yahoo.com
}

Received 20 February 2015; accepted 13 March 2015; published 18 March 2015

Copyright (C) 2015 by author and Scientific Research Publishing Inc. This work is licensed under the Creative Commons Attribution International License (CC BY). http://creativecommons.org/licenses/by/4.0/ (c) $\underset{\mathrm{EY}}{\mathrm{B}}$ Open Access

\begin{abstract}
The greatest service industry and income gainer throughout the world occupies a special role and position in developing geographical areas. This study attempts to use "Reynard" model to investigate the role of tourism and its effects on the development of rural settlements with emphasis on Pa Ggaleh Village, which is one of the environs in Mamasani, Iran. Due to its historical and religious attractions and natural and cultural landscapes, this village is highly significant and has the potential to become a tourism hub and attract tourists. The methodology applied in this research is cross-sectional. Tourism potentials of Pa Ghaleh village are identified and evaluated in this study. Geological maps, topographies and field data are used to evaluate the district attractions. Their tourism potentials are also evaluated and rated using Reynard model. According to the sub-criteria of rarity and historical geography, the research results indicate that scientific value has the highest rank. In other words, tourism places in Pa Ghaleh village include $72 \%$ of scientific value, $0.59 \%$ of added value and $0.57 \%$ of compound value.
\end{abstract}

\section{Keywords}

Rural Tourism, Sustainable Rural Development, Reynard Model, Pa Ghaleh Village

\section{Introduction}

In recent decades, the importance of tourism has been significantly increasing both nationally and internationally in terms of the number of tourists and foreign currency income [1]. Tourism potentials are based on a systematic 
structure that any tourist needs to know about all tourism conditions and its basic concepts [2]. Recently, rural tourism has received a lot of attention as one of the most important industries which has the required potentials to help local communities in line with developing economic activities [3]. According to the increasing trend of rural area destruction and the decline of agricultural activities, the rural tourism which is known as an alternative approach for achieving sustainable rural development attempts to present a new strategy to revive rural areas through complementary activities or to transform them according to natural and human resources [4]. This kind of tourism promotes the environment survival and is a positive and instructive experience for tourists. It is practically a form of sustainable tourism dependent on rural environment. Moreover, tourism brings native people in direct contact with environments and improves their knowledge and awareness regarding environment and sustainable development [5]. As another considerable aspect of rural tourism in terms of physical condition of villages, maintaining valuable rural textures, traditional houses consistent with the regional climate and various settlement styles have been emphasized [6]. These regions also include ecological, aesthetic, economic and scientific values at the same time and are exploited [7].

The objective framework of sustainable development and ecological landscape planning demands that attempts should be made to study and identify high-potential environmental areas in line with the optimal land development and decreasing environmental pressure on specific areas [8]. Rural area properties provide extensive resources and capitals for developing various tourist activities. These resources and capitals do not suffice tourist activities and it is necessary to supply resources and facilities based on market demands. In order to be able to provide tourists and visitors with tourist resources, the resources need to be transformed to tourist products so that they can be consumed by the tourists. Transforming tourist resources and attractions requires them to be invested and prepared [9].

Pa Ghaleh village is one of the villages of Fars Province in Iran which has high potentials in terms of tourism. Pa Ghaleh village as the most important tourism hub of the province on one hand because of the specific ecological properties and environmental capabilities and because of historical and cultural heritage on the other hand, has highly significant potential opportunities, facilities and capabilities. It has many advantages to attract tourists which in general can significantly influence the economics of the region. In this study, attempts have been made to study the rural tourism status of sustainable development in Pa Ghaleh village by Reynard model in addition to identification of areas prone to tourism development and investigation of their properties.

\section{Materials and Research Methodology}

The cross-sectional research methodology has been applied in this study and field study has been conducted to gather data. Then, the area location was specified by studying geological maps, topography and field visits from the area. In the next phase of the research [10], was applied to analyze the data with the purpose of valuing tourist locations in line with maintaining and exploiting geomorphologic, geological, cultural and historical heritages. The criteria used in this method are divided into 6 categories, each comprised of several subcategories (Table 1).

The real evaluation is based on three criteria of scientific, added and compound values and qualitative and quantitative strategies have been applied to calculate them. Scientific value includes the protection condition, indicator, rarity and attraction in terms of paleogeography. Paleogeography is of high importance in scientific value because it helps to analyze ground condition and weather history. Paleogeography's subcategories are significant due to the history of the Earth and climate (Table 2). The added value is comprised of four criteria of ecologic value, aesthetic value, cultural (religious, historical, artistic, literary and historical land) value and economic value. Although this part cannot provide a complete analysis of the location under study in all economic, ecologic and historical aspects, it can ultimately establish an appropriate relationship between geomorphology of the location and tourism (Table 3).

The global value subcategory in compound value is highly significant because the region is globally unique. Tourist infrastructures and officials' management practices and advertisement are also taken into consideration (Table 4). The values are presented in the corresponding tables and scorings are done based on the aforementioned indices. The scores are between 0 (lowest score) and 1 (highest score). Corresponding specialists commented on value scores. Therefore, each value is presented using a specific score and the total value of the research area is estimated. 
Table 1. Criteria for Reynard evaluation method.

\begin{tabular}{ll}
\hline Categories and criteria & Subcategories \\
\hline 1) General data & Code, location, type and properties \\
2) Descriptive data & a) Anatomy, b) morphogenesis \\
3) Scientific value & a) Maintainance condition, b) indicator, c) rarity, d) paleogeography \\
4) Added value & a) Ecological value, b) aesthetic value, c) cultural value, d) economic value \\
5) Compound & a) Global value, b) educational value, c) threats, d) level of management
\end{tabular}

\section{Table 2. Criteria for the evaluation of scientific value in Reynard model.}

\begin{tabular}{|c|c|}
\hline Criteria & Evaluation criteria \\
\hline Protection condition & $\begin{array}{l}\text { Protection condition of geosite is considered. Inappropriate } \\
\text { protection might be due to erosion or human factors. }\end{array}$ \\
\hline Indicator & An indicator geosite whose process example is distinctive and prominent. \\
\hline Rarity & $\begin{array}{l}\text { Location rarity compared to the general atmosphere of the area or a rare and unique } \\
\text { geomorphologic location related to the research area in the past. }\end{array}$ \\
\hline $\begin{array}{l}\text { Location attraction in } \\
\text { terms of paleo geology }\end{array}$ & $\begin{array}{l}\text { Importance of the location in terms of climate and ground history which studies the geographical } \\
\text { condition of the earth in the past or geological attraction of the geomorphologic location. }\end{array}$ \\
\hline
\end{tabular}

Table 3. Criteria for the evaluation of added value in Reynard model.

\begin{tabular}{|c|c|}
\hline Criteria & Evaluation criteria \\
\hline Ecological value & $\begin{array}{l}\text { 1. Ecological impacts: specific ecosystem in the region or plant and animal species specific to the region. } \\
\text { 2. Protected area: significantly important due to sensitivity. }\end{array}$ \\
\hline Aesthetic value & $\begin{array}{l}\text { 1. Personal viewpoint: viewer's perception based on his observation of the location. } \\
\text { 2. Location structure and properties: contradictions in natural landscapes of the area (such as color } \\
\text { contradictions in landscapes and contradictions between rocks). }\end{array}$ \\
\hline Cultural value & $\begin{array}{l}\text { 1. Religious indices: Mystical and mythical values of the research location. } \\
\text { 2. Historical indices: including the ancient history, prehistoric and temporary periods which can attract } \\
\text { tourists. Moreover, this criterion is not only responsible to record subjects related to political history, } \\
\text { but it is also important in tourism. } \\
\text { 3. Literary and artistic indices: presence of the research location in artistic perceptions such as paintings, } \\
\text { lithographs, books and poems. } \\
\text { 4. Geological history: presence of phenomena in the research location which are geologically important } \\
\text { and discuss the history of transformations and evolution of the earth from the beginning until today. }\end{array}$ \\
\hline Economic value & $\begin{array}{l}\text { The economic value of the research location can be determined and estimated qualitatively and quantitatively } \\
\text { through products available in a geosite. }\end{array}$ \\
\hline
\end{tabular}

Table 4. Criteria for the evaluation of compound value in Reynard model.

\begin{tabular}{|c|c|}
\hline Criteria & Evaluation criteria \\
\hline Global value & $\begin{array}{l}\text { Global value is the sum of qualitative and quantitative results of scientific } \\
\text { value and the added values of geosite. }\end{array}$ \\
\hline Educational value & The importance of the research location for education (schools, universities). \\
\hline Threat level & Potential threats available in research location might be due to human impacts or natural processes. \\
\hline Management level & Level of management practices suggested to maintain and improve the research location. \\
\hline
\end{tabular}

\section{Introducing Research Location}

Pa Ghaleh village is one of the environs of Doshman Ziari in Mamasani Province with geographical coordinates of $52^{\circ} 1$ 'East, $30^{\circ}$ North, within $70 \mathrm{~km}$ of South East Mamasani and $75 \mathrm{~km}$ of North West Shiraz which is located in the eastern Zagros mountains (Figure 1). The village is $1945 \mathrm{~km}$ above the sea level. The weather is moderate 


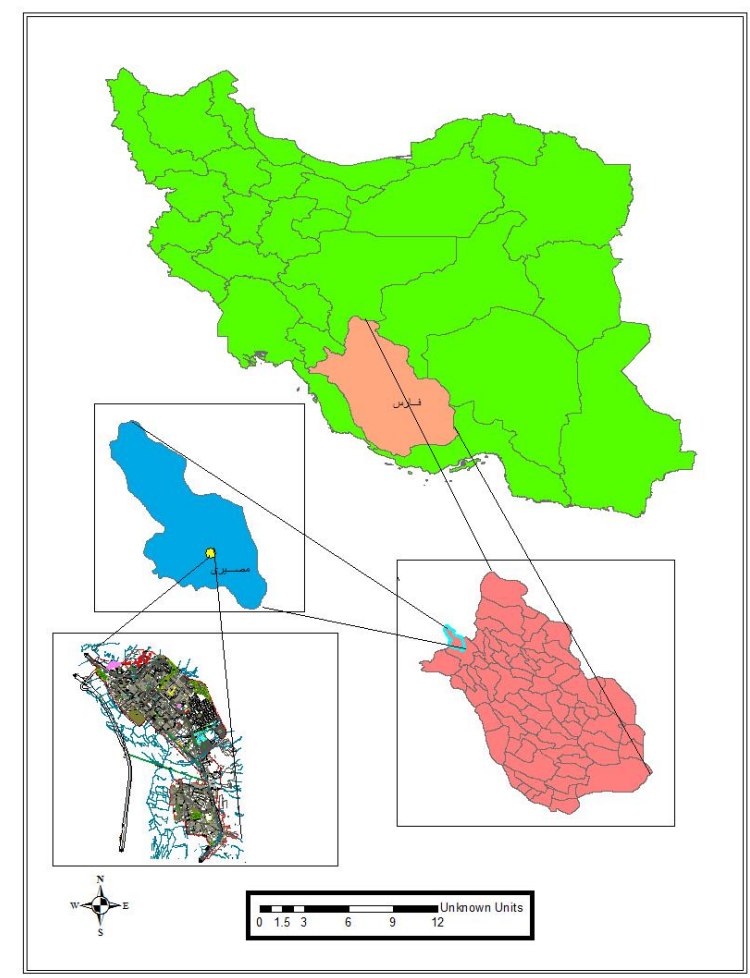

Figure 1. Station of Village Paghale in Mamasani County.

in spring and summer and it is cold in winter. The mountainous Pa Ghaleh village is located on a steep slope and it has a compact stair residential texture. The residential units are two-floored. The ground floor is used to keep and the upper floor is used to live in. Most of the materials used in cottages include rocks, clay, woods, bricks and plaster. Handcraft products of this village include rugs, kilims and jajims. In the last two centuries this area has been one of the temporary settlements of nomads, which in Qajar period was turned into a village. Tourism attractions in Pa Ghaleh include: Pa Ghaleh waterfall which is one of the most beautiful and tallest waterfall in Fars Province. Two high level springheads called Khatiri which pass through beautiful gardens and hills and run through rock walls in the lower hand of the village supply its water. At the upper hand of the waterfall and around the village there are numerous ancient hills which are remnants of different historical eras and indicate the long history of human settlement in the area. Khatiri spring in the North West of the village supplies the water required for gardens and agricultural lands of the village. Shesh Pir River near the village passes through a strait which is covered by timbers of Zagros. Grasslands and natural pastures in the Eastern hills of the village are stunning. Large green gardens in the Western part of the village that is extended through a beautiful hill grant $\mathrm{Pa}$ Ghaleh village with a special grace, especially in spring.

\section{Data Analysis}

According to the field visits and results obtained from expert opinions, each value was scored in Reynard model. The scores obtained from the evaluation of scientific value, added value and compound value of the research location allow their comparison (Table 5).

Tourism assessment is the most important part of the activity because the future policy development and future tourism plans can be decided upon, especially if concepts such as sustainable tourism are considered. The level of the capability of each area can be easily achieved which consequently can provide correct management and protection to achieve tourism development in the area. According to the data provided in the above table, the scores related to the evaluation of scientific value in the research location show that the rarity and paleogeology subcategories with scores of 0.78 and 0.83 , respectively have the highest scores. Also the high attraction of this area is due to its paleogeology, geological age and geological heritage. Being an indicator and protection condition with 0.75 and 0.52 scores, respectively are in the next ranks. 
Table 5. The mean of evaluation scores by Reynard model (Reynard et al., 2007).

\begin{tabular}{|c|c|c|c|}
\hline Value & Subcategory & Obtained score & Tota \\
\hline \multirow{4}{*}{ Scientific value } & Protection & 0.52 & \multirow{4}{*}{0.72} \\
\hline & Indicator & 0.75 & \\
\hline & Rarity & 0.78 & \\
\hline & Paleogeography & 0.83 & \\
\hline \multirow{9}{*}{ Added value } & Ecological impacts & 0.72 & \multirow{9}{*}{0.59} \\
\hline & Protected location & 0.65 & \\
\hline & Personal viewpoint & 0.80 & \\
\hline & Location structure & 0.82 & \\
\hline & Religious importance & 0.21 & \\
\hline & Historical importance & 0.42 & \\
\hline & $\begin{array}{l}\text { Artistic-literary } \\
\text { importance }\end{array}$ & 0.32 & \\
\hline & $\begin{array}{l}\text { Historical land } \\
\text { importance }\end{array}$ & 0.75 & \\
\hline & Economic products & 0.45 & \\
\hline \multirow{4}{*}{ Compound value } & Global value & 0.75 & \multirow{4}{*}{0.57} \\
\hline & Educational value & 0.87 & \\
\hline & Threats & 0.31 & \\
\hline & Management level & 0.35 & \\
\hline
\end{tabular}

Source: Analytical research findings, 2014.

In added value, the location structure and personal viewpoint subcategories have 0.82 and 0.80 scores, respectively. External beauty, potential of teaching geosciences, especially fluvial erosion, historical land and stair texture of villages are the reasons of this subcategory receiving the highest score in terms of aesthetic value. The economic production score of 0.45 in this location is one of the important issues that should be taken into consideration. The economic production in this area is developed as a result of officials support from rural tourism development with an approach towards employment, the possibility of improving and expanding communication network between cities and villages, more attempts to introduce the village as the sample area of tourism, bringing variety to tourist products in the village in order to attract tourists throughout the year. Educational value has the highest score of 0.87 among subcategories of compound value. A comparison of evaluations indicate that scientific value, added value and compound value have the highest and lowest amount of scores with scores of $0.72,0.59$ and 0.57 , respectively. The mean of total value is 0.62 .

Finally, it can be stated that Pa Ghaleh village with various tourist attractions in different natural, physicalspatial (related to houses and rural architecture), historical, socio-cultural aspects can be introduced as a tourist place. Therefore, it can be considered as one of the tourist and natural resources. Protecting natural and cultural properties of the village which are known as national heritages and tourist attractions and which attract tourists from all over the world, give a new identity to the residents of this village.

\section{Conclusion}

According to various aspects of rural tourism, countries with rural tourist attraction attempt to improve and use it. Iran is also considered as one of these countries. Pa Ghaleh village in Fars Province is also included. In an overall conclusion of the assessments done, by analyzing the scientific value (protection condition, indicator, rarity and attraction in terms of palegeology) and added value through four evaluation criteria of ecologic value, aesthetic value, cultural (religious, historical, artistic, literary and historical land) value, economic value and 
compound value (global value, educational value, threats and management levels) in Pa Ghaleh village, it was specified that the scientific value, added value and compound value have $0.72,0.59$ and 0.57 scores, respectively. Apart from having natural attractions (rivers, waterfalls and springs) and old historical texture (such as ancient castle and stair texture), the village has a unique texture with brick architecture and native culture, which not only saves the identity of the village, but also improves the sustainable development of tourism. The research results in these areas show that they are highly potential in attracting tourists and can significantly help to decrease poverty and provide job opportunities in attracting tourists; especially if tourism industry has utilized natural and human resources directly and in the form of physical-spatial (related to houses and stair architecture of the village) and socio-cultural aspects to improve villages economically. In this regard, higher public and government awareness will end in sustainable development and also prevent humanitarian disasters. It also guarantees the dynamics of rural tourism.

\section{References}

[1] Thomas, R., Pigozzi, B. and Sambrook, R. (2005) Tourist Carrying Capacity Measures: Crowding Syndrome in the Caribean. The Professional Geographer, 57, 13-20.

[2] Fennell, D.A. (1999) Ecotourism: An Introduction. Routledge Publication, London.

[3] Byrd, E., Bosley, H. and Dronberger, M. (2009) Comparisons of Stakeholder Perceptions of Tourism Impacts in Rural Eastern North Carolina. Tourism Management, 30, 693-730. http://dx.doi.org/10.1016/j.tourman.2008.10.021

[4] Holland, G., Burian, M. and Dixey, L. (2003) Tourism in Poor Rural Areas, Diversifying the Product and Expanding the Benefits in Rural Uganda and the Czech Republic.

[5] Butter, R. and Stephan, B. (2004) Tourism and National Park. Johan Wiley \& Sons, Ltd., England, 466 p.

[6] Mahdavi, M., Ghadiri, M. and Ghahremani, N. (2000) Tourism Impacts on Rural Development: Survey from Villagers of Dare Kan and Solghan. Quarterly of Villages and Development, 11, 39-60.

[7] Pereira, P., Pereira, D., Caetano, M. and Braga, A. (2007) Geomorphosite Assessment in Montesinho Natural Park (Portugal). Geographica Helvetica, 62, 159-168. http://dx.doi.org/10.5194/gh-62-159-2007

[8] Michaeli, A.R. (2002) Tourism Planning Based on Ecological Principles. Geographical Research Magazine, 39, 21-28.

[9] Rezvani, M. (2001) Rural Tourism: Principles and Concepts. Tehran University Press, Tehran.

[10] Reynard, E., Fontana, G., Kozlik, L. and Scapozza, C. (2007) A Method for Assessing Scientific and Additional Value of Geomorphosites. Geographica Helvetica, 62, 148-158. http://dx.doi.org/10.5194/gh-62-148-2007 